\title{
Reclassification of a Polycyclic Aromatic Hydrocarbon-Metabolizing Bacterium, Beijerinckia sp. Strain B1, as Sphingomonas yanoikuyae by Fatty Acid Analysis, Protein Pattern Analysis, DNA-DNA Hybridization, and 16S Ribosomal DNA Sequencing
}

\author{
ASHRAF A. KHAN, RONG-FU WANG, WEI-WEN CAO, WIRT FRANKLIN, \\ AND CARL E. CERNIGLIA* \\ Microbiology Division, National Center for Toxicological Research, \\ Food and Drug Administration, Jefferson, Arkansas 72079
}

\begin{abstract}
A bacterium isolated from a polluted stream, capable of metabolizing biphenyl, naphthalene, phenanthrene, and higher-molecular-weight polycyclic aromatic hydrocarbons (D. Gibson, V. Mahadevan, D. Jerina, H. Yagi, and H. Yeh, Science 189:295-297, 1975), was previously identified as Beijerinckia sp. strain B1. In this investigation, 16S rRNA gene sequencing, biochemical tests, fatty acid methyl ester analysis, polyacrylamide gel electrophoresis of protein, and DNA-DNA hybridization were used to determine the taxonomic relationship of Beijerinckia sp. strain B1. The sequence of the 16S rRNA gene of B1 was identical to that of Sphingomonas yanoikuyae ATCC 51230 ${ }^{\mathrm{T}}$. The biochemical tests, fatty acid analysis, and sodium dodecyl sulfate-polyacrylamide gel electrophoresis profile of soluble proteins of strain B1 showed results similar to those of $S$. yanoikuyae. DNA-DNA hybridization indicated that B1 and $S$. yanoikuyae ATCC $51230^{\mathrm{T}}$ are $75 \%$ homologous at the DNA level. We propose that Beijerinckia sp. strain $\mathrm{B} 1$ be reclassified as $S$. yanoikuyae.
\end{abstract}

A strain designated Beijerinckia sp. strain B1 was originally isolated for its ability to grow with biphenyl as a carbon and energy source (6). This organism can utilize biphenyl, naphthalene, and phenanthrene as sole sources of carbon and energy and co-oxidize a wide variety of polycyclic aromatic hydrocarbons to carbon dioxide and mixtures of ring fission products $(1,6,8,9,12)$. Biphenyl-induced cells of a mutant of this strain, B8/36, oxidize biphenyl, anthracene, phenanthrene, benzo $[a]$ pyrene, and benz $[a]$ anthracene to $c i s$-dihydrodiols (1, $6,8,9,12,17)$. The metabolic pathway for the degradation of benz $[a]$ anthracene is inducible by biphenyl, salicylate, and $m$ xylene (12). Because of the wide range of polycyclic aromatic hydrocarbons degraded by this organism, extensive genetic and metabolic pathway studies have been done $(1,3,6,8,9)$. Molecular analysis of the enzymes involved in aromatic degradation has been reported by Kim and Zylstra (10).

Since strain B1 has potential use in the bioremediation of polycyclic aromatic hydrocarbon-contaminated environmental sites, we reevaluated the identification of Beijerinckia sp. strain B1 by using biochemical tests, DNA-DNA hybridization, sodium dodecyl sulfate-polyacrylamide gel electrophoresis (SDSPAGE) soluble protein analysis, fatty acid methyl ester (FAME) analysis, and 16S rRNA gene sequence analysis.

\section{MATERIALS AND METHODS}

Bacterial strains. Beijerinckia sp. strain B1 was provided by David T. Gibson University of Iowa, Iowa City. The other bacterial strains used in this study were Beijerinckia indica ATCC $21423^{\mathrm{T}}$ ( $\mathrm{T}=$ type strain), Escherichia coli ATCC 33694, Sphingomonas paucimobilis ATCC $29837^{\mathrm{T}}$, S. yanoikuyae ATCC $51230^{\mathrm{T}}$, and Pseudomonas putida ATCC $12633^{\mathrm{T}}$. The bacteria were cultured at $28^{\circ} \mathrm{C}$ in shake flasks containing PG medium consisting of (per liter) $5.0 \mathrm{~g}$ of peptone, 2.5 $\mathrm{g}$ of glucose, $1.3 \mathrm{~g}$ of $2 \mathrm{~K}_{2} \mathrm{HPO}_{4}, 0.5 \mathrm{~g}$ of $\mathrm{MgSO}_{4} \cdot 7 \mathrm{H}_{2} \mathrm{O}, 0.5 \mathrm{~g}$ of $\mathrm{KNO}_{3}$, and 0.06 $\mathrm{g}$ of $\mathrm{Ca}\left(\mathrm{NO}_{3}\right) \cdot 4 \mathrm{H}_{2} \mathrm{O}(\mathrm{pH} 7.2)$. Cells were grown for $24 \mathrm{~h}$ at $28^{\circ} \mathrm{C}$ on Trypticase soy broth agar prepared by dissolving $30 \mathrm{~g}$ of Trypticase soy broth (BBL no. 11768 ) and $15 \mathrm{~g}$ of granulated agar (BBL no. 11849) in 1 liter of distilled water.

* Corresponding author. Phone: (501) 543-7341. Fax: (501) 5437307. Electronic mail address: CCERNIGLIA@FDANT.NCTR.FDA GOV.
Biochemical profiles. Media used for biochemical characterization were prepared by the method of Weaver et al. (22). The bacterium was characterized by using a scheme for the identification of unusual pathogenic gram-negative bacteria (22) at $35^{\circ} \mathrm{C}$.

FAME analysis. Bacterial cultures were harvested from Trypticase soy broth-5\% sheep blood agar for total cellular fatty acid analysis. Fatty acids were extracted by following the Microbial Identification System (MIDI; Microbial ID, Inc., Newark, Del.) instructions.

Preparation of soluble protein fractions. The bacterial strains listed above were grown on Trypticase soy broth $-5 \%$ sheep blood agar plates for $16 \mathrm{~h}$ at $30^{\circ} \mathrm{C}$. Several colonies were combined in $300 \mu \mathrm{l}$ of Tris- $\mathrm{HCl}(20 \mathrm{mM}, \mathrm{pH} 6.8)$ and sonicated for 430 -s pulses at maximum power with 30 -s cooling intervals in an ice bath. Unbroken cells and large fragments were removed by low-speed $(3,000 \times$ g) centrifugation on a Sorvall RC-5B centrifuge (Dupont-Sorvall, Newtown, Conn.) with an SS-34 rotor for $10 \mathrm{~min}$. The soluble protein for the SDS-PAGE protein profile was collected after centrifuging the lysate at $23,425 \times g$ and $4^{\circ} \mathrm{C}$ for $30 \mathrm{~min}$ with an SS-34 rotor. The supernatant was stored at $-20^{\circ} \mathrm{C}$ until profile analysis. SDS-PAGE was performed by the method of Laemmli (11). Proteins solubilized in sample buffer were stacked in a $4.5 \%$ (wt/vol) acrylamide gel (100-V constant voltage) and separated on a $10 \%(\mathrm{wt} / \mathrm{vol})$ acrylamide gel (120 V). Gels were stained with Coomassie blue R-250 (0.25\%)-10\% acetic acid in methanol and destained in $10 \%$ methanol- $10 \%$ acetic acid in distilled water. Protein concentration was determined by using the bicinchoninic acid protein assay reagent (Pierce Chemical Co., Rockford, Ill.) (18). Bovine serum albumin was used as the standard.

DNA-DNA hybridization. DNAs from $S$. paucimobilis ATCC $29837^{\mathrm{T}}, S$. yanoikuyae ATCC $51230^{\mathrm{T}}$, and strain $\mathrm{B} 1$ were hybridized with radiolabeled DNA from strain B1. Chromosomal DNA was isolated by using the Easy-DNA kit (Invitrogen, San Diego, Calif.) as recommended by the manufacturer. DNA was quantified spectrophotometrically at $260 \mathrm{~nm}$. DNA from each strain was denatured in $0.4 \mathrm{M} \mathrm{NaOH}-10 \mathrm{mM}$ EDTA, and 1.0- $\mu \mathrm{g}$ portions were transferred onto a nylon membrane (GeneScreen Plus; Dupont, Wilmington, Del.) with a slot blot vacuum manifold (Bethesda Research Laboratories, Inc., Gaithersburg, Md.). The blot was neutralized with $0.5 \mathrm{M}$ Tris- $\mathrm{HCl}(\mathrm{pH} 7.5)$ and cross-linked with a UV cross-linker (Stratagene, La Jolla, Calif.). DNA $(1 \mu \mathrm{g})$ from strain B1 was labeled with $\left[\alpha-{ }^{32} \mathrm{P}\right] \mathrm{dCTP}$ as the sole labeling nucleotide by nick translation as instructed by the supplier (Bethesda Research Laboratories, Inc.). Unincorporated nucleotides were removed by passing the mixture through Sephadex G-50 filters. Slot blots were prehybridized in $10 \mathrm{ml}$ of prehybridization solution in sealable plastic bags at $65^{\circ} \mathrm{C}$ for $20 \mathrm{~h}(13)$. Denatured, labeled probe was added to the blots, and the preparations were hybridized for $20 \mathrm{~h}$ at $60^{\circ} \mathrm{C}$. The membrane was washed and rinsed as already described by using the standard protocol for GeneScreen Plus nylon membrane plus one additional wash in $0.1 \times$ SSC $(1 \times$ SSC is $0.15 \mathrm{M}$ $\mathrm{NaCl}$ plus $0.015 \mathrm{M}$ sodium citrate) plus $0.1 \% \mathrm{SDS}$ for $30 \mathrm{~min}$ at the hybridization temperature. After the final wash, the membrane was rinsed in $0.1 \times \mathrm{SSC}$. The membranes were wrapped in plastic wrap and exposed to $\mathrm{X}$-ray film at $-70^{\circ} \mathrm{C}$. The extent of hybridization on the membrane was determined by scintillation 


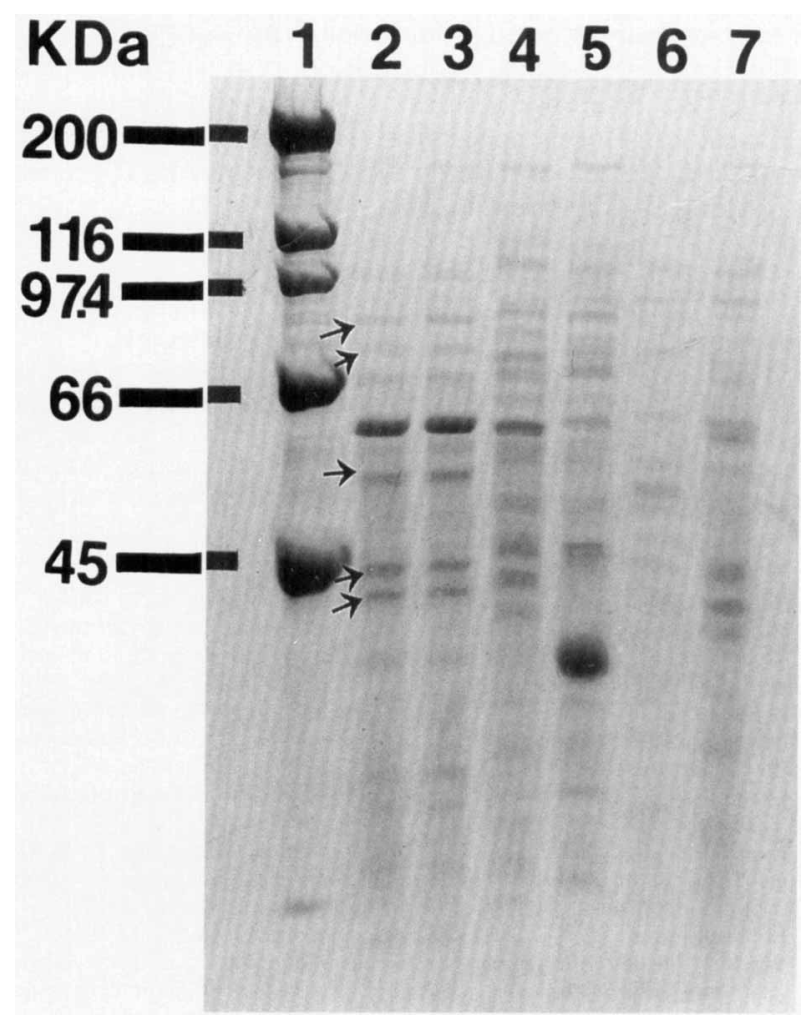

FIG. 1. SDS-PAGE profiles of soluble proteins from strain B1 (lane 2), $S$. yanoikuyae (lane 3), S. paucimobilis (lane 4), B. indica (lane 5), E. coli (lane 6), and $P$. putida (lane 7 ). Samples containing $10 \mu \mathrm{g}$ of total protein were subjected to electrophoresis on an SDS-10\% polyacrylamide resolving gel, and the protein bands were detected by staining with Coomassie blue R-250. Lane 1 contained molecular weight markers (high-molecular-weight range; Bio-Rad). The arrows indicate the protein bands unique to strain $\mathrm{B} 1$ and $S$. yanoikuyae but not the other strains.

counting. There were three replications for each strain randomized on three blots.

In vitro amplification of the $16 \mathrm{~S}$ rRNA gene. The rRNA gene was amplified in vitro by the PCR technique with primers Amp-1, 5'-GAGAGTTTGATYCTGG CTCAG-3' (identical to sequence positions 7 to 27 in the Escherichia coli numbering system [2]), and Amp-2, 5'-AAGGAGGTGATCCARCCGCA-3' (complementary to positions 1540 to 1521 in the $E$. coli numbering system). Strain B1 was grown overnight at $28^{\circ} \mathrm{C}$ in tryptic soy broth. A $1.5-\mathrm{ml}$ sample was centrifuged to pellet the cells. The cells were washed twice with phosphate-buffered saline ( $\mathrm{pH} \mathrm{7.2)} \mathrm{and} \mathrm{once} \mathrm{with} \mathrm{autoclaved,} \mathrm{distilled} \mathrm{water} \mathrm{and} \mathrm{then} \mathrm{suspended} \mathrm{in}$ $0.1 \mathrm{ml}$ of distilled water. The cells were diluted $1: 10$ by using $100 \mu \mathrm{l}$ of $1 \%$ Triton $\mathrm{X}-100$. The samples were then heated at $100^{\circ} \mathrm{C}$ for $5 \mathrm{~min}$, immediately cooled in ice water, and subjected to PCR amplification without isolation of the DNA. A 3.5- $\mu \mathrm{l}$ sample was added to $45 \mu \mathrm{l}$ of the PCR mixture containing $50 \mathrm{mM}$ Tris- $\mathrm{HCl}$ (pH 8.5); $20 \mathrm{mM} \mathrm{KCl} ; 3 \mathrm{mM} \mathrm{MgCl} ; 0.05 \%$ bovine serum albumin (no. A-4378; Sigma Chemical Co., St. Louis, Mo.); $0.25 \mathrm{mM}$ each dATP, dTTP, dCTP, and dGTP; $0.25 \mu \mathrm{M}$ each primer; and 1.8 $\mathrm{U}$ of Taq polymerase (Promega, Madison, Wis.). The PCR was carried out in a Perkin-Elmer DNA thermal cycler 480
(Perkin-Elmer Cetus Corp., Norwalk, Conn.). The PCR cycle parameters were as follows: preheating for $3 \mathrm{~min}$ at $95^{\circ} \mathrm{C}$, denaturation for $20 \mathrm{~s}$ at $95^{\circ} \mathrm{C}$, annealing for $20 \mathrm{~s}$ at $55^{\circ} \mathrm{C}$, and extension for $60 \mathrm{~s}$ at $74^{\circ} \mathrm{C}$. After $35 \mathrm{cycles}$, the final step was incubation for $3 \mathrm{~min}$ at $74^{\circ} \mathrm{C}$. The lengths of the amplified fragments were determined by electrophoresis in an agarose $(1 \%$, wt/vol) gel containing ethidium bromide in TAE buffer (13)

Sequence determination. Amplification primers Amp-1 and Amp-2 were also used as sequencing primers with eight other sequencing primers; U2, RU2, U3, RU3, U6, RU6, U7, and RU7, which are located in the internal conserved regions of the 16S rRNA gene sequence. The primer sequences and their locations were described previously (21). The amplified DNA (about $1.5 \mathrm{~kb}$ ) was visualized with a longwave UV lamp and excised from the agarose gel. The Glassmilk method (Geneclean II kit; Bio 101, Inc., La Jolla, Calif.) was used to recover the DNA. Direct sequencing of the PCR products was done with the SequiTherm Cycle Sequencing Kit (Epicentre Technologies, Madison, Wis.) with $\left[{ }^{35}\right.$ S $]$ dATP.

Phylogenetic analysis. The $16 \mathrm{~S}$ rRNA gene sequence of Beijerinckia sp. strain B1 was compared with those of other, related species available from GenBank. Homology analysis and rooted tree construction were conducted by using the MegAlign computer program (DNASTAR Inc., Madison, Wis.).

Nucleotide sequence accession number. The nucleotide sequence of the $16 \mathrm{~S}$ rRNA gene of strain B1 has been deposited in the GenBank (EMBL) database under accession number $\mathrm{X} 85023$.

\section{RESULTS AND DISCUSSION}

Phenotype and biochemical characteristics. Strain B1 was gram negative with a single polar flagellum. The colonies were light yellow, oxidase-positive catalase producers. In biochemical tests, strain B1 had reactions identical to those of $S$. yanoikuyae (23). It was distinguished from the related species $S$. paucimobilis by acidic reactions on $10 \%$ glucose and lactose. In addition, both strain B1 and $S$. yanoikuyae ATCC $51230^{\mathrm{T}}$ utilized Simmons citrate; however, $S$. paucimobilis was unable to utilize Simmons citrate. This observation is in agreement with Yabuuchi et al. (23), who proposed five Sphingomonas species on the basis of biochemical tests, unique sphingoglycolipids, isoprenoid quinones (Q-10), DNA-DNA hybridization, and phenotypic characteristics.

SDS-PAGE analysis of soluble proteins. The protein profiles of strain B1, S. paucimobilis ATCC $29837^{\mathrm{T}}$, S. yanoikuyae ATCC $51230^{\mathrm{T}}$, and B. indica ATCC $21423^{\mathrm{T}}$ were compared (Fig. 1). The SDS-PAGE protein profile of strain B1 was similar to that of $S$. yanoikuyae (Fig. 1, lanes 2 and 3) but not to that of $S$. paucimobilis or B. indica. Five bands from both strain B1 and $S$. yanoikuyae, with molecular masses of $84,76,58,45$, and 41 $\mathrm{kDa}$, were observed. These five bands were not observed in the profile of $S$. paucimobilis ATCC $29837^{\mathrm{T}}, B$. indica ATCC $21423^{\mathrm{T}}$, or E. coli ATCC 33694 (Fig. 1).

Fatty acid analysis. The total cellular FAMEs from strain B1, S. yanoikuyae ATCC $51230^{\mathrm{T}}$, and $S$. paucimobilis ATCC $29837^{\mathrm{T}}$ were determined. Strain B1 showed a fatty acid profile identical to that of $S$. yanoikuyae when the samples were extracted from Trypticase soy broth-5\% sheep blood agar plates. The $S$. paucimobilis strain, under similar culture conditions, did not show any match. We used Trypticase soy broth-5\% sheep blood agar plates for FAME analysis because strains ATCC

\section{Euclldlan Distance}

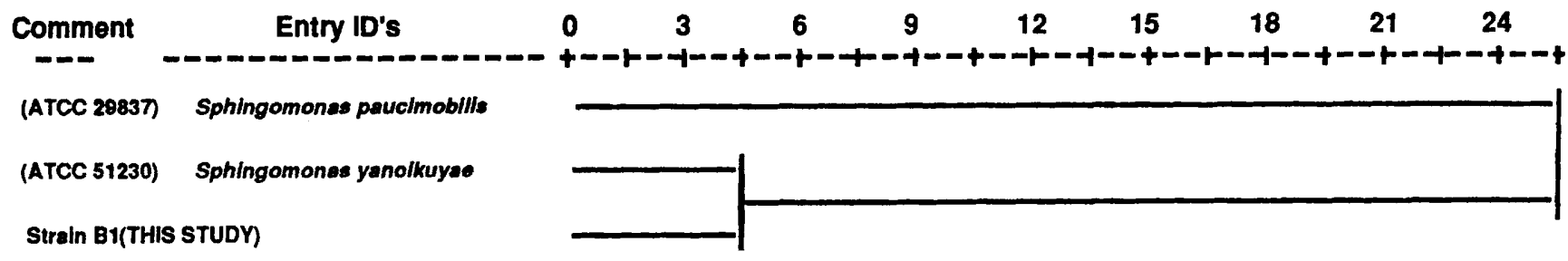

FIG. 2. Dendrogram of strain B1 and closely related strains generated by cluster analysis of FAME profiles. ID, identification. 


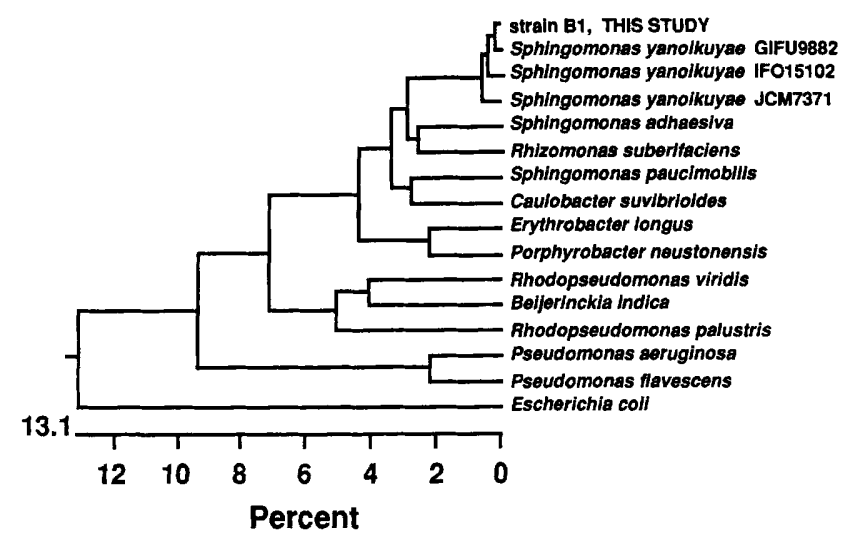

FIG. 3. Phylogenetic rooted tree constructed with the MegAlign computer program (DNASTAR Inc.) by using the 16S rRNA gene sequence data of strain B1. The scale indicates base difference percentages.

$51230^{\mathrm{T}}$ and ATCC $29837^{\mathrm{T}}$ are clinical isolates. A dendrogram based on the fatty acid composition of strain B1, S. yanoikuyae, and $S$. paucimobilis was created by cluster analysis (Fig. 2). The relationships of the FAME profile of strain $\mathrm{B} 1$ to the other two are depicted in the dendrogram (Fig. 2) based on the coefficients of similarity generated by the euclidean distances between pairs of bacteria. These data indicate that strain B1 is similar to $S$. yanoikuyae ATCC $51230^{\mathrm{T}}$. Similar dendrograms have been used to subgroup the clinical isolates of $P$. cepacia (15).

DNA-DNA hybridization. The DNA relatedness of strain B1 was confirmed by DNA hybridization with labeled DNA of strain B1. S. yanoikuyae ATCC $51230^{\mathrm{T}}$ exhibited $75 \%$ DNA homology with labeled B1 DNA at $60^{\circ} \mathrm{C}$. The level of DNA hybridization of strain B1 with S. paucimobilis ATCC $29837^{\mathrm{T}}$ was $54 \%$ under similar conditions.

Nucleotide sequence of the 16S rRNA gene and phylogenetic analysis. The $16 \mathrm{~S}$ rRNA gene sequence of strain B1 $(1,445 \mathrm{bp})$ was determined and deposited in the GenBank (EMBL) database under accession number X85023. Phylogenetic analysis was conducted by comparing the $16 \mathrm{~S}$ rRNA gene sequence of strain B1 with those of other, closely related species and $B$. indica from the GenBank database. The sequences exhibited high levels of similarity to Sphingomonas spp. but not to Beijerinckia sp. For example, the strain B1 $16 \mathrm{~S}$ rRNA gene was identical to that of S. yanoikuyae GIFU9882 (ATCC 51230 ${ }^{\mathrm{T}}$ ) but had a lower sequence similarity to that of $B$. indica ATCC $21423^{\mathrm{T}}$. A rooted tree (Fig. 3) indicates that strain B1 belongs to the genus Sphingomonas, is far removed from $B$. indica, and clusters with three sequences of $S$. yanoikuyae.

Sphingomonas spp. are relatively common in soil, water, and sediments $(4,5)$. Fredrickson et al. (4) isolated several aromatic hydrocarbon-degrading bacteria from southeastern coastal plain subsurface sediments and found that they belong to the genus Sphingomonas. Similarly, Takeuchi et al. (20) reported that several polyethylene glycol-degrading bacteria, previously identified as Pseudomonas sp. or Flavobacterium sp., were actually Sphingomonas spp. Other Pseudomonas spp. that metabolize biphenyl (19), naphthalene, toluene, and xylene (5), polycyclic aromatic hydrocarbons (14), halogenated diphenyl ethers (16), and hexachlorocyclohexane (7) have been reclassified in the genus Sphingomonas recently. Thus, it is not surprising that strain B1, a polycyclic aromatic hydrocarbondegrading bacterium, belongs in the genus Sphingomonas.

In conclusion, $16 \mathrm{~S}$ rRNA gene sequence analysis, biochem- ical tests, cellular fatty acid profile, soluble protein (SDS-PAGE) profile, and DNA-DNA hybridization results confirm that strain B1 is a reference strain of $S$. yanoikuyae. The phylogenetic position of this species was also established. The sequence can be used to develop DNA probes or PCR primers for tracking $S$. yanoikuyae in soil.

\section{ACKNOWLEDGMENTS}

We thank David T. Gibson for kindly providing strain B1.

This research was supported in part by appointments to the Postgraduate Research Program at the National Center for Toxicological Research administered by the Oak Ridge Institute for Science and Education through an interagency agreement between the U.S. Department of Energy and the U.S. Food and Drug Administration.

\section{REFERENCES}

1. Akhtar, M. N., D. R. Boyd, N. J. Thomas, M. Koreeda, D. T. Gibson, V. Mahadevan, and D. M. Jerina. 1975. Absolute stereochemistry of the dihydroanthracene-cis- and trans-1,2-diols produced from anthracene by mammals and bacteria. J. Chem. Soc. Perkin Trans. 1:2506-2511.

2. Brosius, J., J. L. Palmer, J. P. Kennedy, and H. F. Noller. 1978. Complete nucleotide sequence of a $16 \mathrm{~S}$ ribosomal RNA gene from Escherichia coli. Proc. Natl. Acad. Sci. USA 75:4801-4805.

3. Cerniglia, C. E. 1993. Biodegradation of polycyclic aromatic hydrocarbons. Curr. Opin. Biotechnol. 4:331-338.

4. Fredrickson, J. K., D. L. Balkwill, G. R. Drake, M. F. Romine, D. B. Ringelberg, and D. C. White. 1995. Aromatic-degrading Sphingomonas isolates from the deep subsurface. Appl. Environ. Microbiol. 61:1917-1922.

5. Fredrickson, J. K., F. J. Brockman, D. J. Workman, S. W. Li, and T. O. Stevens. 1991. Isolation and characterization of a subsurface bacterium capable of growth on toluene, naphthalene, and other aromatic compounds. Appl. Environ. Microbiol. 57:796-803.

6. Gibson, D., V. Mahadevan, D. Jerina, H. Yagi, and H. Yeh. 1975. Oxidation of the carcinogens benzo $[a]$ pyrene and benz $[a]$ anthracene to dihydrodiols by a bacterium. Science 189:295-297.

7. Imai, R., Y. Nagata, M. Fukuda, M. Takagi, and K. Yano. 1991. Molecular cloning of a Pseudomonas paucimobilis gene encoding a 17-kilodalton polypeptide that eliminates $\mathrm{HCl}$ molecules from $\gamma$-hexachlorocyclohexane. J. Bacteriol. 173:6811-6819.

8. Jerina, D., H. Selander, H. Yagi, M. Wells, J. Davey, V. Mahadevan, and D. T. Gibson. 1976. Dihydrodiols from anthracene and phenanthrene. J. Am. Chem. Soc. 98:5988-5996.

9. Jerina, D. M., P. J. van Bladeren, H. Yagi, D. T. Gibson, V. Mahadevan, A. S. Neese, M. Koreeda, N. D. Sharma, and D. R. Boyd. 1984. Synthesis and absolute configuration of the bacterial cis-1,2-, cis-8,9-, and cis-10,11-dihydrodiol metabolites of benz $[a]$ anthracene formed by a strain of Beijerinckia. J. Org. Chem. 49:3621-3628.

10. Kim, E., and G. J. Zylstra. 1995. Molecular and biochemical characterization of two meta-cleavage dioxygenases involved in biphenyl and $m$-xylene degradation by Beijerinckia sp. strain B1. J. Bacteriol. 177:3095-3103.

11. Laemmli, U. K. 1970 . Cleavage of structural proteins during the assembly of the head bacteriophage T4. Nature (London) 227:680-685.

12. Mahaffey, W. R., D. T. Gibson, and C. E. Cerniglia. 1988. Bacterial oxidation of chemical carcinogens: formation of polycyclic aromatic acids from benz[a]anthracene. Appl. Environ. Microbiol. 54:2415-2423.

13. Maniatis, T., E. F. Fritsch, and J. Sambrook. 1982. Molecular cloning: a laboratory manual. Cold Spring Harbor Laboratory, Cold Spring Harbor, N.Y.

14. Mueller, J. G., P. J. Chapman, B. O. Blattmann, and P. H. Pritchard. 1990. Isolation of a fluoranthene-utilizing strain of Pseudomonas paucimobilis. Appl. Environ. Microbiol. 56:1079-1086.

15. Mukwaya, G. M., and D. F. Welch. 1989. Subgrouping of Pseudomonas cepacia by cellular fatty acid composition. J. Clin. Microbiol. 27:2640-2646.

16. Schmidt, S., R.-M. Wittich, D. Erdmann, H. Wilkes, W. Francke, and P. Fortnagel. 1992. Biodegradation of diphenyl ether and its monohalogenated derivatives by Sphingomonas sp. strain SS3. Appl. Environ. Microbiol. 58: 2744-2750.

17. Schocken, M. J., and D. T. Gibson. 1984. Bacterial oxidation of the polycyclic aromatic hydrocarbons acenaphthene and acenaphthylene. Appl. Environ. Microbiol. 48:10-16.

18. Smith, P. K., R. L. Krohn, G. T. Hermanson, A. K. Mallia, F. H. Garter, M. D. Provenzano, E. K. Fujimoto, N. M. Goeke, B. J. Olson, and D. C. Klenk. 1985. Measurement of protein using bicinchoninic acid. Anal. Biochem. 150:76-85.

19. Taira, K., N. Hayase, N. Arimura, S. Yamashita, T. Miyazaki, and K. Furukawa. 1988. Cloning and nucleotide sequence of the 2,3-dihydroxybiphenyl dioxygenase gene from the PCB-degrading strain of Pseudomonas paucimobilis Q1. Biochemistry 27:3900-3996. 
20. Takeuchi, M., H. Sawada, H. Oyaizu, and A. Yokota. 1994. Phylogenetic evidence for Sphingomonas and Rhizomonas as nonphotosynthetic members of the alpha-4 subclass of the Proteobacteria. Int. J. Syst. Bacteriol. 44:308314.

21. Wang, R.-F., W.-W. Cao, and C. E. Cerniglia. 1996. Phylogenetic analysis of Fusobacterium prausnitzii based upon 16S rRNA gene sequence and PCR confirmation. Int. J. Syst. Bacteriol. 46:341-343.

22. Weaver, R. E., D. G. Hollis, W. A. Clark, and P. Riley. 1983. The identifi- cation of unusual pathogenic gram negative bacteria, p. 39. Centers for Disease Control, Atlanta.

23. Yabuuchi, E., I. Yano, H. Oyaizu, Y. Hasimoto, T. Ezaki, and H. Yamamoto. 1990. Proposals of Sphingomonas paucimobilis gen. nov. and comb. nov. Sphingomonas parapaucimobilis sp. nov., Sphingomonas yanoikuyae sp. nov., Sphingomonas adhaesiva sp. nov., Sphingomonas capsulate comb. nov., and two genospecies of the genus Sphingomonas. Microbiol. Immunol. 34:99119. 